\title{
Kelimpahan dan Keanekaragaman Polychaeta Pada Jenis Mangrove yang Berbeda di Tahura Ngurah Rai
}

\author{
Luh Pt Priyandayani a*, I Gede Hendrawan ${ }^{a}$, Widiastutia \\ aProgram Studi Ilmu Kelautan, Fakultas Kelautan dan Perikanan, Universitas Udayana, Kampus UNUD Bukit Jimbaran, Bali 80361, Indonesia
}

Penulis koresponden. Tel.: +62-812-363-16740

Alamat e-mail: luhputupriyandayani@gmail.com

Diterima (received) 16 Juli 2017; disetujui (accepted) 27 Oktober 2017; tersedia secara online (available online) 30 Oktober 2017

\begin{abstract}
Mangrove at Tahura Ngurah Rai Bali contributes the organic material into environment. Polychaeta is one of the main benthic macrofauna that has important role in accumulating organic material to mangrove ecosystem. The purpose of this research is to explain the abundance and diversity of Polychaeta such as Rhizophora mucronata, mix mangrove and Sonneratia alba at Tahura Ngurah Rai. The sampling of Polychaeta using corers with diameter $17 \mathrm{~cm}$ and height $18 \mathrm{~cm}$ those sink in the substrate. The abundance was analyzed by the Krebs and diversity was analyzed by Shannon Wiener index. There were five genus of Polychaeta, such as Heteromastus, Marphysa, Laeonereis, Nereis, and Paranaitis. The highest abundance of Polychaeta was found in mixed stations $\left(432 \pm 57,37 \mathrm{ind} / \mathrm{m}^{2}\right)$, and the lowest abundance was in R. mucronata $\left(414 \pm 79,93 \mathrm{ind} / \mathrm{m}^{2}\right)$. The abundance of Polychaeta in the three stations did not differ significantly because it was influenced by the dominant substrate of sandy clay. The highest Polychaeta diversity was found in $S$. alba $(0,704)$, followed by the mixed station $(0,642)$, and the lowest was in $R$. mucronata. The value of Polychaeta diversity on the three stations differed significantly because of the comparison between the type and total number of individuals in each station that varied. The Polychaeta diversity index in the three stations is low, while the Polychaeta abundance value in each station is quite abundant. The result showed that the stability of the Polychaeta community in the mangrove ecosystem is unstable.
\end{abstract}

Keywords: mix mangrove; polychaeta; Rhizophora mucronata; Sonneratia alba; Tahura Ngurah Rai

\begin{abstract}
Abstrak
Komposisi jenis mangrove yang heterogen di kawasan hutan mangrove Tahura Ngurah Rai Bali berperan penting sebagai penyumbang bahan organik bagi lingkungan sekitarnya. Polychaeta merupakan salah satu makrofauna bentik utama yang berperan penting dalam akumulasi bahan organik pada ekosistem mangrove. Tujuan penelitian ini adalah untuk mengetahui kelimpahan dan keanekaragaman Polychaeta pada jenis mangrove Rhizophora mucronata, mangrove campuran dan Sonneratia alba di Tahura Ngurah Rai. Pengambilan sampel Polychaeta pada masing-masing jenis mangrove dilakukan dengan menggunakan corer yang berdiameter $17 \mathrm{~cm}$ dan tinggi $18 \mathrm{~cm}$ dengan cara dibenamkan pada substrat. Kelimpahan Polychaeta dianalisa dengan persamaan Krebs dan keanekaragaman Polychaeta dianalisa dengan indeks Shannon Wiener. Hasil penelitian menunjukkan bahwa Polychaeta yang terdapat pada jenis mangrove R. mucronata, mangrove campuran dan S. alba yaitu genus Heteromastus, Marphysa, Laeonereis, Nereis, dan Paranaitis. Kelimpahan Polychaeta tertinggi terdapat pada stasiun mangrove campuran yaitu sebesar $432 \pm 57,37 \mathrm{ind} / \mathrm{m}^{2}$, sedangkan kelimpahan terendah pada stasiun $R$. mucronata $\left(414 \pm 79,93 \mathrm{ind} / \mathrm{m}^{2}\right)$. Kelimpahan Polychaeta pada ketiga stasiun tidak berbeda secara signifikan karena dipengaruhi oleh substrat yang dominan yaitu lempung berpasir. Keanekaragaman Polychaeta tertinggi terdapat pada stasiun S. alba yaitu sebesar 0,704, diikuti dengan stasiun mangrove campuran sebesar 0,642, dan terendah terdapat pada stasiun $R$. mucronata. Keanekaragaman Polychaeta pada ketiga stasiun berbeda secara signifikan karena perbandingan antara jenis dan jumlah total individu pada masing-masing stasiun yang bervariasi. Indeks keanekaragaman Polychaeta pada ketiga stasiun tergolong rendah, sedangkan nilai kelimpahan Polychaeta pada masing-masing stasiun tergolong agak melimpah. Hal ini menunjukkan bahwa komunitas Polychaeta pada ekosistem mangrove dalam keadaan tidak stabil.
\end{abstract}

Kata Kunci: mangrove campuran; polychaeta; Rhizophora mucronata; Sonneratia alba ; Tahura Ngurah Rai 


\section{Pendahuluan}

Ekosistem mangrove merupakan salah satu ekosistem yang paling produktif dan memiliki nilai ekologi yang tinggi (Muhammad et al., 2013). Produktivitas primer ekosistem mangrove mencapai $5.000 \mathrm{gr} \mathrm{C} / \mathrm{m}^{2} /$ th. Masukan unsur hara melalui biomassa serasah (guguran daun, bunga, ranting dan sejumlah bagian pohon lain yang jatuh) menyebabkan tingginya produktivitas primer pada ekosistem mangrove (Feller et al. 2010; Andrianto et al., 2015).

Tingginya produktivitas primer pada ekosistem mangrove merupakan hasil dari aktivitas makrofauna bentik yang merupakan elemen utama yang mempengaruhi tingginya tingkat dekomposisi dari detritus dan pendaur ulang nutrien (Pendleton et al., 2012). Polychaeta, Kepiting, Gastropoda, Bivalvia, Teritip, Spong, Tunikata, dan Sipuncula merupakan kelompok terbesar penyusun komunitas makrofauna pada ekosistem mangrove (Vazirizadeh et al., 2011). Diantara kelompok makrofauna bentik tersebut Polychaeta merupakan komponen dominan penyusun baik dari segi jumlah spesies dan individu yaitu sebanyak $60-80 \%$ dari populasi makrofauna bentik (Shou et al., 2009). Permukaan substrat yang kaya akan kandungan C-organik menjadikan hutan mangrove sebagai habitat ideal untuk Polychaeta (Quintana et al., 2013). Distribusi dan kelimpahan Polychaeta sangat terkait dengan kandungan C-organik yang tersedia di daerah mangrove (Samidurai et al., 2012).

Secara ekologi Polychaeta berperan penting dalam menjaga stabilitas sedimen dasar laut dan proses dekomposisi bahan organik pada ekosistem mangrove (Murugesan et al., 2016). Ketika proses dekomposisi bahan organik berjalan stabil, suplai unsur hara ke dalam substrat akan tetap terjaga (Siska et al., 2016). Kandungan unsur hara yang terakumulasi pada substrat akan mempengaruhi kesuburan pada ekosistem mangrove (Andrianto et al., 2015). Selain menjaga kesuburan pada ekosistem mangrove, Polychaeta juga berperan sebagai penentu kesuburan suatu perairan, yang secara tidak langsung dapat diperkirakan dengan mengukur kelimpahan, komposisi spesies dan biomassa.

Salah satu kawasan hutan mangrove yang memiliki komposisi jenis dan spesies mangrove beragam dengan zonasinya yang unik di Bali adalah Tahura Ngurah Rai. Kawasan mangrove yang mengelilingi Teluk Benoa ini didominasi oleh ekosistem mangrove alami dan rehabilitasi. Komposisi jenis mangrove yang beragam menyebabkan kawasan hutan mangrove Tahura Ngurah Rai dijadikan sebagai kawasan ekowisata sepanjang $1,4 \mathrm{~km}$ yang dikenal dengan nama Mangrove Trail (Martiningsih et al., 2015). Selain itu, secara ekologi Tahura Ngurah Rai juga berperan penting dalam penyuplai bahan organik bagi lingkungan perairan di sekitarnya. Rhizophora mucronata, Sonneratia alba dan mangrove campuran merupakan jenis mangrove yang menyusun vegetasi di sepanjang Mangrove Trail, dimana masing-masing daun dari ketiga jenis mangrove tersebut memiliki struktur daun dan susunan kimia yang berbeda (Puspayanti et al., 2013; Suriani et al., 2017). Serasah yang berasal dari mangrove yang berbeda memiliki struktur morfologi yang berbeda, dimana perbedaan tersebut akan mempengaruhi proses dekomposisi masing-masing mangrove (Dharmawan et al., 2016) dan kelimpahan Polychaeta yang berperan sebagai dekomposer (Sibaja-Cordero and Echeverría-Sáenz, 2015). Jenis mangrove yang berbeda dapat menghasilkan produktivitas primer yang berbeda pula (Aida et al., 2014). Oleh karena itu, mengingat pentingnya peran hutan mangrove Tahura Ngurah Rai tersebut, maka melalui kelimpahan dan keanekaragaman Polychaeta secara tidak langsung dapat diketahui produktivitas primer yang dihasilkan. Penelitian ini untuk mengetahui kelimpahan dan keanekaragaman Polychaeta pada jenis mangrove Rhizophora mucronata, mangrove campuran dan Sonneratia alba di Tahura Ngurah Rai.

\section{Metode Penelitian}

\subsection{Waktu dan Tempat}

Pengambilan sampel Polychaeta dilaksanakan pada tanggal 19-20 Januari 2017 di area Mangrove Trail Tahura Ngurah Rai (Gambar 1). Analisis sampel Polychaeta dilakukan di Laboratorium Ilmu Kelautan Fakultas Kelautan dan Perikanan dan Laboratorium Biologi Fakultas Matematika dan Ilmu Pengetahuan Alam Universitas Udayana. Sementara itu, uji tekstur substrat dan C-organik dilakukan di Laboratorium Tanah Fakultas Pertanian Universitas Udayana. 

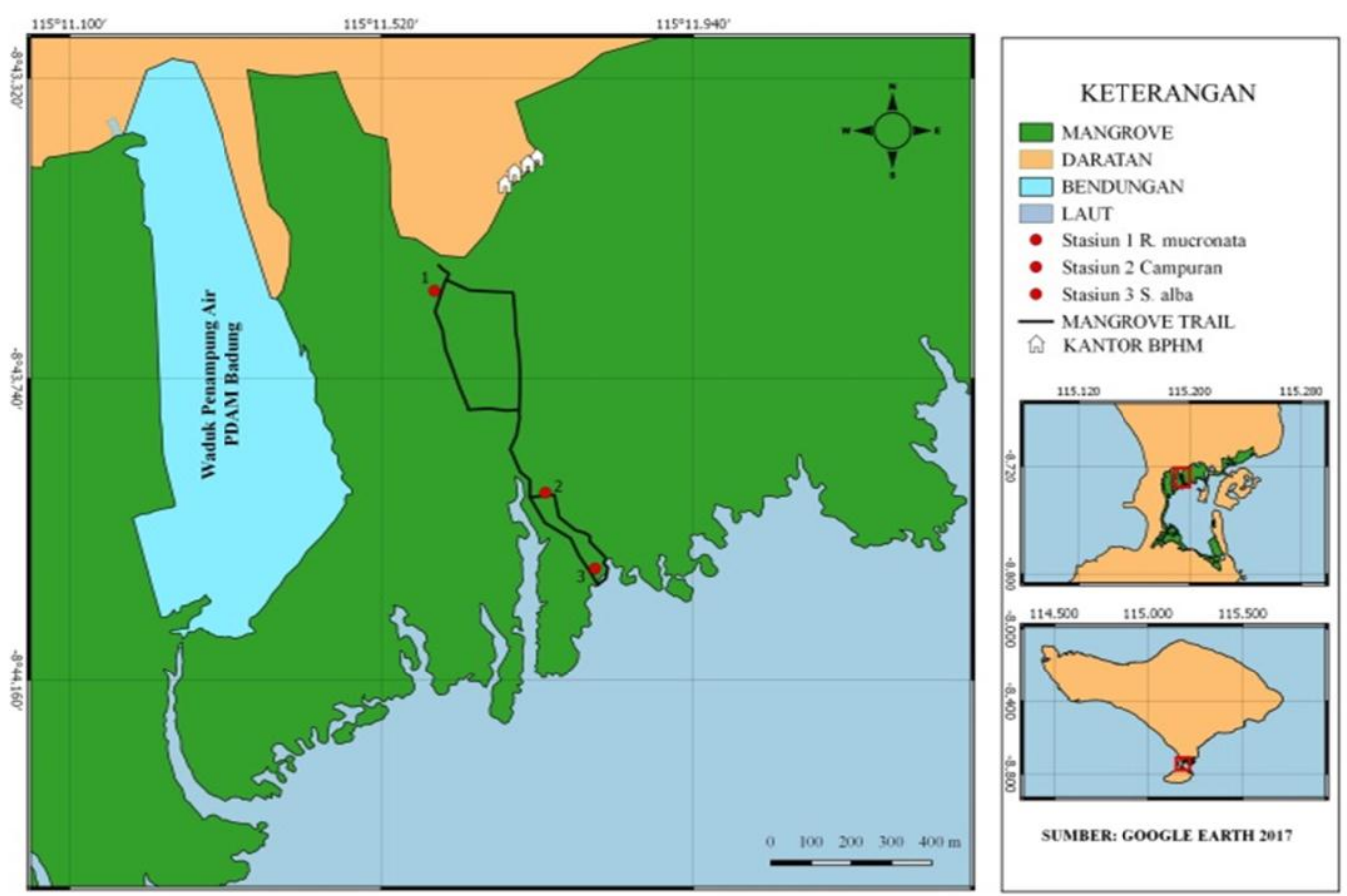

Gambar 1. Peta lokasi penelitian

\subsection{Metode Pengambilan Data}

\subsubsection{Pengambilan Sampel Polychaeta}

Pengambilan sampel dilakukan pada saat kondisi surut terendah dengan alasan agar mempermudah dalam pengambilan sampel dan tidak terkendala dengan arus serta gelombang. Penentuan stasiun pengamatan didasarkan atas jenis mangrove yaitu sampel Polychaeta diambil dari 3 stasiun yaitu jenis mangrove Rhizophora mucronata (stasiun 1), mangrove campuran (stasiun 2) dan Sonneratia alba (stasiun 3)(Gambar 1). Jenis mangrove yang terdapat pada stasiun mangrove campuran terdiri dari Aegiceras corniculatum, Rhizophora apiculata, Avicennia marina, dan Sonneratia alba. Pada masingmasing stasiun dibuat transek kuadrat untuk tingkatan pohon dengan ukuran $20 \times 20$ meter (Hasri et al., 2014). Terdapat 5 titik pengambilan sampel Polychaeta secara acak pada masingmasing stasiun. Metode pengambilan sampel Polychaeta dilakukan menurut Bodil et al. (2011) yaitu menggunakan alat pipa yang berlubang (corer) untuk pengambilan sampel sedimen dengan diameter $17 \mathrm{~cm}$ dan tinggi $18 \mathrm{~cm}$ yang dibenamkan pada substrat. Substrat yang telah diambil kemudian disaring dengan saringan bentos dengan ukuran mesh 0,5 mm (Fauchald, 1977).
Sampel Polychaeta yang telah didapat dimasukkan ke dalam wadah plastik kemudian diawetkan dengan formalin $4 \%$ selama 24 jam, kemudian dibilas dengan air tawar, lalu disimpan dalam wadah yang berisi alkohol 70\% (Fauchald, 1977). Sampel Polychaeta lalu diidentifikasi, dihitung kelimpahan serta keanekaragamannya.

\subsubsection{Pengukuran Parameter Fisika dan Kimia}

Beberapa parameter yang diamati secara in situ, yaitu suhu dan $\mathrm{pH}$. Parameter fisika yang diukur meliputi tekstur dan tipe substrat, sedangkan parameter kimia yang diukur adalah kandungan C-organik. Pengambilan sampel substrat dilakukan dengan membenamkan corer sedalam 18 $\mathrm{cm}$ dan memindahkan substrat ke dalam kantung plastik. Pada setiap stasiun diambil 200 gram sampel substrat, lalu di bawa ke laboratorium untuk dikering-anginkan. Sampel substrat tersebut kemudian dianalisis kandungan tekstur dan tipe substrat serta kandungan C-organik.

\subsection{Analisis Data}

\subsubsection{Identifikasi Data Polychaeta}

Identifikasi Polychaeta dilakukan sampai dengan takson terendah yang dapat dicapai, dengan 
berpedoman pada buku kunci identifikasi menurut Day (1967) dan Fauchald (1977).

\subsubsection{Kandungan Substrat}

Kandungan substrat yang diukur adalah tekstur substrat dan C-organik. Penetapan komposisi tekstur substrat diuji dengan menggunakan metode pipet. Penetapan tersebut dilakukan dengan menggunakan bantuan segitiga tekstur terhadap komposisi substrat yang diperoleh. Penetapan jenis substrat didasarkan pada presentasi berat dari pasir, debu dan liat. Kandungan C-organik substrat diuji dengan metode Walkley dan Black. Nilai konsentrasi Corganik yang diperoleh pada jenis mangrove Rhizophora mucronata didapatkan dari substrat yang mengandung serasah-serasah yang berasal dari jenis mangrove Rhizophora mucronata, sedangkan konsentrasi C-organik pada jenis mangrove Sonneratia alba berasal dari substrat yang mengandung serasah mangrove Sonneratia alba. Konsentrasi C-organik yang diperoleh pada jenis mangrove campuran berasal dari substrat yang mengandung serasah mangrove campuran.

\subsubsection{Kelimpahan Polychaeta}

Kelimpahan Polychaeta dihitung berdasarkan persamaan 1 (Krebs, 1989).

$$
D i=\frac{n i}{A}
$$

Keterangan:

Di = kelimpahan $\left(\right.$ ind $\left./ \mathrm{m}^{2}\right)$

$\mathrm{ni}=\sum$ total individu jenis $\mathrm{ke}-\mathrm{i}$

$\mathrm{A}=$ luas penampang $\left(\mathrm{m}^{2}\right)$

Stolyarov (1996) menyatakan bahwa nilai kelimpahan terdiri dari beberapa kriteria yaitu:

$$
\begin{array}{ll}
\text { 0-200 } & \text { : tidak melimpah } \\
200-500 & \text { : agak melimpah } \\
500-1000 & \text { : melimpah } \\
>1000 & \text { : sangat melimpah }
\end{array}
$$

\subsubsection{Keanekaragaman Polychaeta}

Keanekaragaman Polychaeta dihitung berdasarkan indeks keanekaragaman Shannon Wiener. Persamaan indeks keanekaragaman Shannon Wiener (Krebs, 1989) ditunjukkan pada persamaan 2.

$$
H^{\prime}=-\sum_{i=1}^{S} p i \ln p i
$$

Keterangan:

$H^{\prime}=$ Indeks keanekaragaman Shannon Wiener

$\mathrm{pi}=$ perbandingan jumlah individu tiap spesies per jumlah total individu

Hardjosuwarno (1990) menyatakan bahwa indeks keanekaragaman $\left(\mathrm{H}^{\prime}\right)$ terdiri dari beberapa kriteria yaitu:

$H^{\prime}>3,0$ menunjukkan keanekaragaman sangat tinggi

$H^{\prime}$ 1,6 - 3,0 menunjukkan keanekaragaman tinggi

$H^{\prime}$ 1,0 -1,5 menunjukkan keanekaragaman sedang

$H^{\prime}<1$ menunjukkan keanekaragaman rendah

\subsubsection{Analisis Statistika}

Perbedaan kelimpahan Polychaeta pada masingmasing jenis mangrove dianalisa dengan uji ANOVA satu arah menggunakan software SPSS 24. Sebelum dilakukan uji ANOVA satu arah, data penelitian terlebih dahulu diuji homogenitas dan distribusi normal. Untuk mengetahui seberapa besar pengaruh konsentrasi C-organik terhadap kelimpahan Polychaeta digunakan analisis regresi dengan menggunakan software Microsoft Excel 2010.

\section{Hasil dan Pembahasan}

\subsection{Parameter Fisika dan Kimia}

Hasil pengukuran parameter fisika dan kimia pada ketiga stasiun di Tahura Ngurah Rai ditunjukkan pada Tabel 1.

\section{Tabel 1}

Parameter fisika dan kimia pada masing-masing stasiun di Tahura Ngurah Rai

\begin{tabular}{lcccl}
\hline \multicolumn{1}{c}{ Stasiun } & $\mathrm{pH}$ & $\begin{array}{c}\text { Suhu } \\
\left({ }^{\circ} \mathrm{C}\right)\end{array}$ & $\begin{array}{c}\text { C-organik } \\
(\%)\end{array}$ & $\begin{array}{l}\text { Tekstur } \\
\text { Substrat }\end{array}$ \\
\hline R. mucronata & 7,5 & 30,0 & 4 & $\begin{array}{l}\text { Lempung } \\
\text { Berpasir } \\
\text { Mangrove }\end{array}$ \\
$\begin{array}{l}\text { campuran } \\
\text { S.alba }\end{array}$ & 7,0 & 29,1 & 3,5 & $\begin{array}{l}\text { Lempung } \\
\text { Berpasir } \\
\text { Lempung } \\
\text { Berpasir }\end{array}$ \\
\hline
\end{tabular}

Tabel 1 menunjukkan bahwa suhu substrat pada setiap stasiun memiliki nilai yang tidak jauh 
berbeda. Suhu substrat pada stasiun mangrove campuran lebih rendah daripada suhu pada stasiun R. mucronata dan S. alba dikarenakan waktu pengukurannya dilakukan di pagi hari, sedangkan waktu pengambilan sampel Polychaeta pada stasiun $R$. mucronata dan stasiun S. alba pada siang hari. Kisaran suhu pada ketiga stasiun masih sesuai bagi kehidupan Polychaeta (Romadhoni dan Aunurohim, 2013).

Berdasarkan Tabel 1, nilai $\mathrm{pH}$ substrat pada setiap stasiun tidak memiliki perbedaan yang besar, karena kondisi substrat pada semua stasiun sama yaitu didominasi oleh lempung berpasir. $\mathrm{pH}$ substrat pada masing-masing stasiun bersifat netral, hal tersebut mengindikasikan bahwa ekosistem mangrove di sana masih dalam keadaan baik. Kisaran $\mathrm{pH}$ substrat pada ketiga stasiun masih mendukung kelangsungan hidup Polychaeta yaitu antara 7,0-7,5 (Mustofa et al., 2012).

Tipe kandungan substrat pada ketiga stasiun yaitu lempung berpasir (Tabel 1). Substrat dengan tekstur lempung yang lunak merupakan habitat yang disukai Polychaeta (Hermawan et al., 2015).

Berdasarkan klasifikasi kandungan C-organik substrat, konsentrasi C-organik pada semua stasiun tergolong sedang hingga tinggi (Tabel 1). Konsentrasi C-organik pada ketiga stasiun berbeda secara signifikan (ANOVA satu arah; $\mathrm{P}<0,05$ ), dimana stasiun yang menunjukkan perbedaan adalah $R$. mucronata dan S. alba. Konsentrasi Corganik tertinggi terdapat pada stasiun $R$. mucronata yaitu sebesar $4 \%$. Hal ini diduga karena produksi serasah yang lebih banyak dan kerapatan mangrove yang lebih tinggi dari kedua jenis mangrove lainnya.

\subsection{Kelimpahan dan Keanekaragaman Polychaeta}

Secara umum komposisi genus yang ditemukan pada stasiun pengamatan adalah Heteromastus, Marphysa, Laeonereis, Nereis, dan Paranaitis (Gambar 2).

Kelimpahan Polychaeta pada setiap stasiun ditunjukkan pada Gambar 3. Kelimpahan Polychaeta antar stasiun pengamatan tidak berbeda secara signifikan $(P>0,05)$. Hal tersebut karena tipe substrat pada ketiga stasiun didominasi oleh lempung berpasir. Dengan adanya tipe substrat yang seragam di seluruh stasiun menyebabkan jumlah individu dan jenis Polychaeta yang diperoleh relatif sama. Menurut Stolyarov (1996), kategori kelimpahan Polychaeta pada semua stasiun pengamatan termasuk ke dalam kategori agak melimpah. Nilai kelimpahan Polychaeta yang tertinggi terdapat pada stasiun mangrove campuran yaitu sebesar $432 \mathrm{ind} / \mathrm{m}^{2}$,

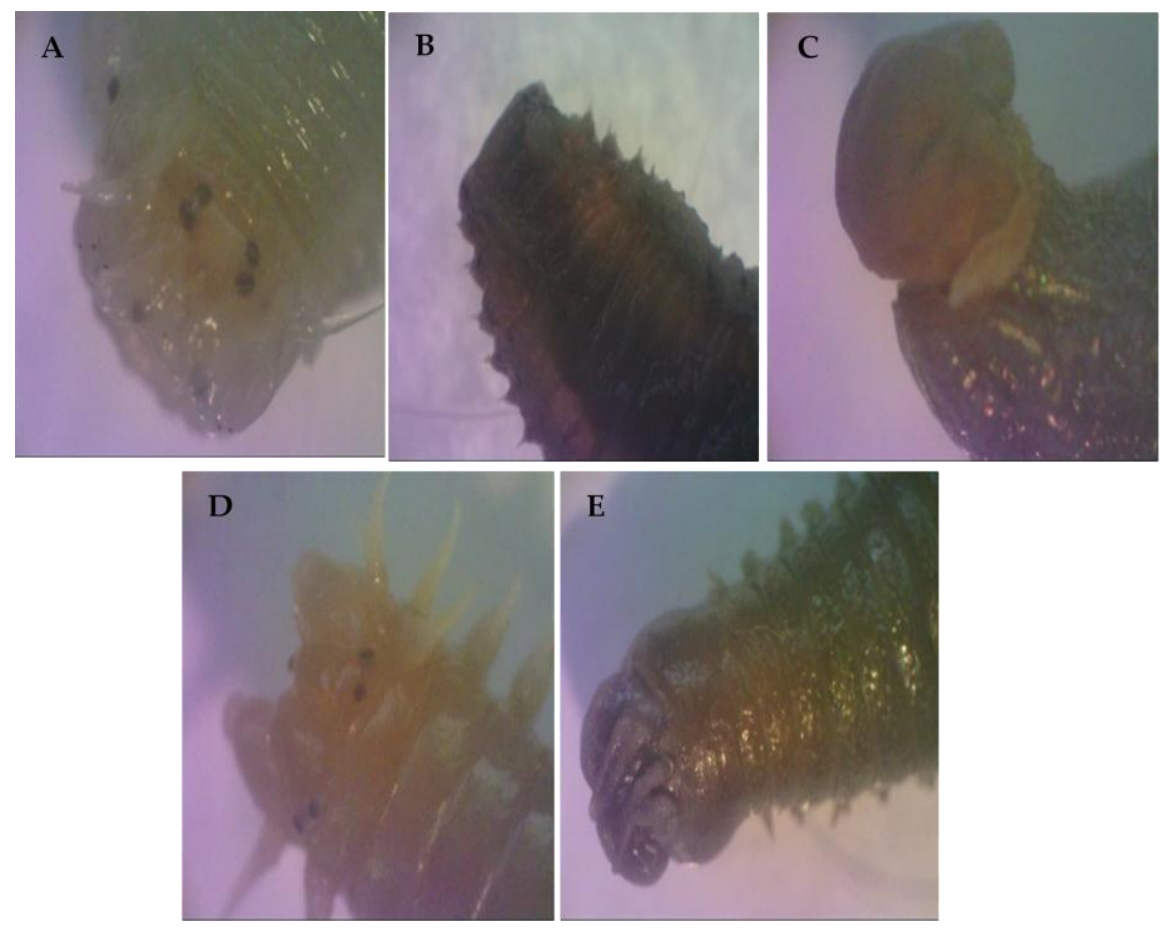

Gambar 2. Genus Polychaeta yang ditemukan pada lokasi penelitian. A Paranaitis; B Nereis; C Heteromastus; D Laeonereis; E Marphysa. 
konsentrasi C-organik yang relatif tinggi pada substrat di stasiun ini mengundang Polychaeta untuk mencari makan sehingga diasumsikan menyebabkan tingginya kelimpahan Polychaeta. Hal ini sesuai dengan pendapat Thilagavathi et al. (2013) yang menyatakan bahwa C-organik merupakan faktor penting dalam kelimpahan Polychaeta yaitu sebagai sumber nutrisi.

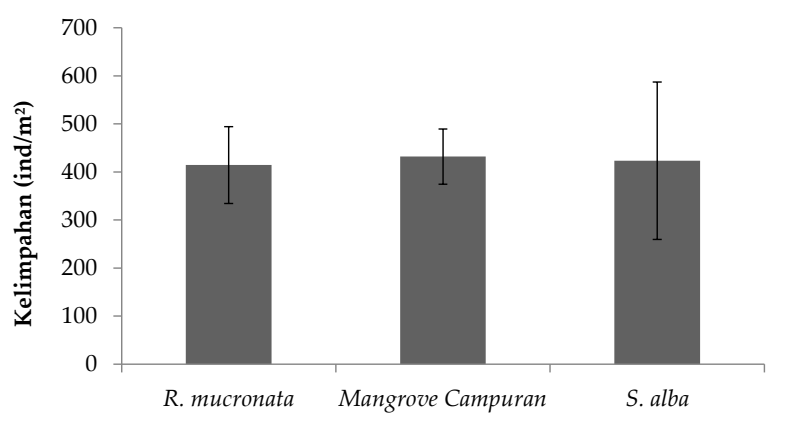

Gambar 3. Kelimpahan Polychaeta pada jenis mangrove R. mucronata, mangrove campuran dan S. alba di Tahura Ngurah Rai

Samidurai et al. (2012) menyatakan bahwa kandungan C-organik yang tinggi menjadi penyebab tingginya kelimpahan Polychaeta di mangrove. Pendapat ini bertentangan dengan hasil yang diperoleh pada stasiun $R$. mucronata. Stasiun R. mucronata menunjukkan kelimpahan Polychaeta terendah dibandingkan stasiun lainnya. Hal ini diduga oleh konsentrasi C-organik yang terkandung dalam substrat $R$. mucronata belum optimal dalam menunjang kehidupan genus Polychaeta yang ditemukan pada stasiun ini (Laeonereis dan Heteromastus). Mahfud et al. (2013) menyatakan bahwa Polychaeta dapat melimpah sebesar $2.134 \mathrm{ind} / \mathrm{m}^{2}$ pada konsentrasi C-organik yang sangat tinggi yaitu 4,89\%-17,66\%. Selain itu, zat tanin atau zat antinutrisi yang terkandung di dalam serasah daun $R$. mucronata juga tidak disukai oleh Polychaeta. Serasah yang mengandung konsentrasi tanin yang tinggi dapat menghambat aktivitas mikroba dan dekomposer karena tannin dapat membentuk ikatan komplek dengan protein sehingga mengganggu aktivitas enzim-enzim pencernaan yang berakibat menghambat pertumbuhan (Robertson, 1988 in Fernando and Bandeira, 2009). Tanin dapat menghambat kerja beberapa jenis enzim seperti enzim protease dan enzim amilase. $R$. mucronata memiliki struktur daun yang tebal dan berkulit, sedangkan S. alba memiliki stuktur daun yang berukuran kecil, halus dan berdaging (Puspayanti et al., 2013). Hal tersebut juga menyebabkan Polychaeta lebih menyukai serasah daun $S$. alba dibandingkan dengan serasah daun $R$. mucronata. Berdasarkan hasil analisis regresi linier, konsentrasi C-organik pada stasiun mangrove campuran dan S. alba hanya mempengaruhi sekitar 1\% kelimpahan Polychaeta, sedangkan kelimpahan Polychaeta yang dipengaruhi konsentrasi C-organik di stasiun $R$. mucronata sekitar $24 \%$.

Keanekaragaman Polychaeta pada stasiun pengamatan ditunjukkan pada Gambar 4. Keanekaragaman Polychaeta tertinggi terdapat pada stasiun $S$. alba yaitu 0,704. Hal tersebut disebabkan oleh konsentrasi C-organik yang terkandung dalam substrat di stasiun ini relatif tinggi, sehingga menjadikannya sebagai sumber nutrien bagi Polychaeta. Hal ini sesuai dengan pendapat Sweetman et al. (2010) yang menyatakan bahwa konsentrasi C-organik yang tinggi dalam substrat akan berdampak pada tingginya keanekaragaman Polychaeta.

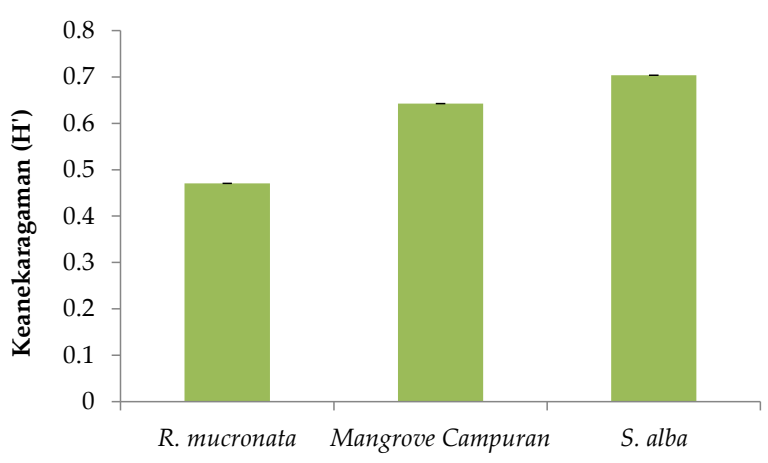

Gambar 4. Keanekaragaman Polychaeta pada jenis mangrove R. mucronata, mangrove campuran dan S. alba di Tahura Ngurah Rai

Selain itu, S. alba memiliki daun yang bernutrisi tinggi yang ditandai oleh rasio $\mathrm{C} / \mathrm{N}$ yang lebih rendah dibandingkan dengan $R$. mucronata (Pendleton et al., 2012). Daun yang bernutrisi tinggi akan menarik Polychaeta untuk memanfaatkan kandungan nutrisi dari serasah daun S. alba sebagai bahan makanan, sehingga diduga menyebabkan tingginya keanekaragaman Polychaeta.

Stasiun $R$. mucronata memiliki keanekaragaman Polychaeta yang paling rendah karena adanya zat tanin yang terkandung di dalam daun, buah, batang, ranting, dan akar pada tubuh $R$. mucronata. Serasah yang berasal dari guguran daun, buah, bunga, dan ranting yang mengandung zat tanin 
tidak disukai oleh Polychaeta. Dugaan ini diperkuat oleh pendapat Romadhoni dan Aunurohim (2013) yang menyatakan bahwa zat tannin akan mengganggu metabolisme Polychaeta.

Menurut Hardjosuwarno (1990), keanekaragaman Polychaeta pada ketiga jenis mangrove termasuk dalam kategori rendah. Hal ini menunjukkan penyebaran dan proporsi setiap genus rendah sehingga cenderung terdapat genus yang mendominasi pada masing-masing jenis mangrove. Ketika terdapat genus yang mendominasi pada suatu habitat, maka dapat mengindikasikan bahwa hanya genus tertentu yang dapat hidup ataupun mentolerir kondisi fisika, kimia dan ekologi pada habitat tersebut.

\section{Simpulan}

Kelimpahan Polychaeta yang ditemukan pada ketiga jenis mangrove di Tahura Ngurah Rai tergolong agak melimpah dengan nilai tertinggi pada jenis mangrove mangrove campuran sebesar $432 \mathrm{ind} / \mathrm{m}^{2}$. Sementara itu, nilai keanekaragaman Polychaeta yang ditemukan umumnya rendah $(<1)$ Keanekaragaman Polychaeta dengan nilai tertinggi ditemukan pada jenis mangrove Sonneratia alba dengan nilai sebesar 0,642 .

\section{Ucapan terimakasih}

Penulis mengucapkan terima kasih kepada Ibu Nur Hayati dan Bapak Simon yang telah membantu selama penelitian di Mangrove Trail Tahura Ngurah Rai; Yesie Rahayu, Eriq Imanuel dan Hasanuddin Parulian S yang telah membantu pengambilan sampel selama penelitian; dan Ibu Suartini (Kepala Laboratorium Biologi FMIPA, Universitas Udayana) yang telah membantu dalam pengamatan Polychaeta.

\section{Daftar Pustaka}

Aida, G. R., Wardiatno, Y., Fahrudin, A., \& Kamal, M. M. (2014). Produksi serasah mangrove di pesisir Tangerang, Banten. Jurnal Ilmu Pertanian Indonesia, 19(2), 91-97.

Andrianto, F., Bintoro, A., \& Yuwono, S. B. (2015). Produksi dan laju dekomposisi serasah mangrove (Rhizophora sp.) di Desa Durian Dan Desa Batu Menyan Kecamatan Padang Cermin Kabupaten Pesawaran. Jurnal Sylva Lestari, 3(1), 9-20.

Bodil, B. A., Ambrose, W. G., Bergmann, M., Clough, L. M., Gebruk, A. V., Hasemann, C., Iken, K., Klages, M.,
MacDonald, I. R., Renaud, P. E., Schewe, I., Soltwedel, T., Włodarska-Kowalczuk, M. (2011). Diversity of the arctic deep-sea benthos. Marine Biodiversity, 41(1), 87107.

Day, J. H. (1967). A monograph on the Polychaeta of southern Africa, Part I (Errantia) \& Part II (Sedentaria). London, UK: Trustees of the British Museum \& Natural History London.

Dharmawan, I. W. E., Zamani, N. P., \& Madduppa, H. H. (2016). Laju dekomposisi serasah daun di ekosistem bakau Pulau Kelong, Kabupaten Bintan. Oseanologi dan Limnologi, 1(1), 1-10.

Fauchald, K. (1977). The Polychaete Worms: Definitions and Key to the Orders, Families and Genera. Natural History Museum of Los Angeles County, Science Series, 28, 1-190.

Feller, I. C., Lovelock, C. E., Berger, U., McKee, K. L., Joye, S. B., \& Ball, M. C. (2010). Biocomplexity in mangrove ecosystems. Annual Review of Marine Science, 2, 395-417.

Fernando, S. M., \& Bandeira, S. O. (2009). Litter fall and decomposition of mangrove species Avicennia marina and Rhizophora mucronata in Maputo Bay, Mozambique. Western Indian Ocean Journal of Marine Science, 8(2), 173-182.

Hardjosuwarno, S. (1990). Dasar-Dasar Ekologi Tumbuhan. Yogyakarta: Fakultas Biologi Universitas Gadjah Mada.

Hasri, K., Basri, H., \& Indra, I. (2014). Dampak alih fungsi lahan terhadap nilai ekosistem mangrove di Kecamatan Seruway Kabupaten Aceh Tamiang. Jurnal Manajemen Sumberdaya Lahan, 3(1), 396-405.

Hermawan, D., Saifullah, S., \& Herdiyana D. (2015). Pengaruh perbedaan jenis substrat pada pemeliharaan cacing laut (Nereis sp.). Jurnal Perikanan dan Kelautan, 5(1), 41-47.

Krebs, C. J. (1989). Ecological methodology (No. QH541. 15. S72. K74 1999.). New York, USA: Harper \& Row Publishers. Inc.

Mahfud, Widianingsih., \& Retno, H. (2013). Komposisi dan kelimpahan makrozoobenthos Polychaeta di Pantai Maron dan Sungai Tapak Kel. Tugurejo, Kec. Tugu, Kota semarang. Journal of Marine Research, 2(1), 134-142.

Martiningsih, N. G. A. G. E., Suryana, I. M., \& Sutiadipraja, N. (2015). Analisa vegetasi hutan mangrove di Taman Hutan Raya (Tahura) Bali. Jurnal Agrimeta, 5(9), 26-36.

Muhammad, F., Hidayat, J. W., \& Mukid, M. A. (2013). Aplikasi Bio-Ekologi Makrobenthos sebagai Indikator Tingkat Kesuburan Tambak. Jurnal Sains Dan Matematika, 21(3), 75-83.

Murugesan, P., Pravinkumar, M., Muthuvelu, S., Ravichandran, S., Vijayalakshmi, S., \& Balasubramanian, T. (2016). Benthic biodiversity in 
natural vis-a-vis artificially developed mangroves of south east coast of India. Indian Journal of Geo-Marine Sciences, 45(8), 1049-1058.

Mustofa, A. G., Harris, E., Supriyono, E., \& Jusadi, D. (2012). Penggunaan substrat pasir untuk budidaya cacing poliket Dendronereis pinnaticirris. Jurnal Akuakultur Indonesia, 11(2), 118-123.

Pendleton, L., Donato, D. C., Murray, B. C., Crooks, S., Jenkins, W. A., Sifleet, S., Craft, C., Fourqurean, J. W., Kauffman, B. J., Marba, N., Megonigal, P., Pidgeon, E., Herr, D., Gordon, D., \& Baldera, A. (2012). Estimating global "blue carbon" emissions from conversion and degradation of vegetated coastal ecosystems. PloS one, 7(9), e43542.

Puspayanti, N. M., Tellu, H. A. T., \& Suleman, S. M. (2013). Jenis-Jenis tumbuhan mangrove di Desa Lebo Kecamatan Parigi Kabupaten Parigi Moutong dan pengembangannya sebagai media pembelajaran. EJurnal online Pendidikan Biologi, 1(1), 1-9.

Quintana, C. O., Kristensen, E., \& Valdemarsen, T. (2013). Impact of the invasive polychaete Marenzelleria viridis on the biogeochemistry of sandy marine sediments. Biogeochemistry, 115(1-3), 95-109.

Romadhoni, M., \& Aunurohim, A. (2013). Struktur Komunitas Polychaeta Kawasan Mangrove Muara Sungai Kali Lamong-Pulau Galang, Gresik. Jurnal Sains dan Seni ITS, 2(2), E212-E217.

Samidurai, K., Saravanakumar, A., \& Kathiresan, K. (2012). Spatial and temporal distribution of macrobenthos in different mangrove ecosystems of Tamil Nadu Coast, India. Environmental monitoring and assessment, 184(7), 4079-4096.

Shou, L., Huang, Y., Zeng, J., Gao, A., Liao, Y., \& Chen, Q. (2009). Seasonal changes of macrobenthos distribution and diversity in Zhoushan sea area. Aquatic Ecosystem Health \& Management, 12(1), 110-115.

Sibaja-Cordero, J. A., \& Echeverría-Sáenz, S. (2015). Polychaetes associated with decaying wood in Térraba mangrove, South Pacific, Costa Rica. Revista de Biología Tropical, 63(1), 61-74.

Siska, F., Sulistijorini, S., \& Kusmana, C. (2016). Litter decomposition rate of Avicennia marina and Rhizophora apiculata in Pulau Dua Nature Reserve, Banten. Journal of Tropical Life Science, 6(2), 91-96.

Stolyarov, A. P. (1996). Zonal distribution of the macrobenthos in the estuary of the Chernaya River (Gulf of Kandalaksha on the White Sea). Oceanographic Literature Review, 4(43), 400.

Suriani, M., Bengen, D. G., \& Prartono, T. (2017). The Production of Organic Matter from Rhizophora mucronata and Sonneratia alba at The Kajhu and Meunasah Mesjid Villages, Aceh Besar. OmniAkuatika, 13(1), 43-53.

Sweetman, A. K., Middelburg, J. J., Berle, A. M., Bernardino, A. F., Schander, C., Demopoulos, A. W. J., \& Smith, C. R. (2010). Impacts of exotic mangrove forests and mangrove deforestation on carbon remineralization and ecosystem functioning in marine sediments. Biogeosciences, 7(7), 21292145.

Thilagavathi, B., Varadharajan, D., Babu, A., Manoharan, J., Vijayalakshmi, S., \& Balasubramanian, T. (2013). Distribution and diversity of macrobenthos in different mangrove ecosystems of Tamil Nadu coast, India. Journal of Aquaculture Research and Development, 4(6), 1-12.

Vazirizadeh, A., Kamalifer, R., Safahieh, A., Mohammadi, M., Khalifi, A., Namjo, F., \& Fakhri, A. (2011). Macrofauna community structure of Bardestan mangrove swamp, Persian Gulf. World Journal of Fish and Marine Sciences, 3(4), 323-331.

(C) 2017 by the authors; licensee Udayana University, Indonesia. This article is an open access article distributed under the terms and conditions of the Creative Commons Attribution license (http://creativecommons.org/licenses/by/3.0/). 